ACTA AGROBOTANICA

Vol. 61 (2): $35-47$

2008

\title{
ECOLOGICAL FEATURES OF AMBROSIA ARTEMISIIFOLIA L. FLOWERS AND CHARACTERISTICS OF AMBROSIA L. POLLEN SEASONS IN THE CONDITION OF LUBLIN (POLAND) IN THE YEARS 2001-2008
}

\author{
Elżbieta Weryszko-Chmielewska, Krystyna Piotrowska
}

\author{
Department of Botany, University of Life Sciences, Akademicka 15, 20-095 Lublin, Poland \\ e-mail: elzbieta.weryszko@up.lublin.pl
}

Received: 19.09.2008

$\mathrm{S}$ u $\mathrm{m} \mathrm{m}$ a $\mathrm{r} \mathrm{y}$

In the study, the biology of flowering of Ambrosia artemisiifolia L. was investigated and the pattern of the Ambrosia pollen seasons in Lublin in the years 2001-2008 was characterised. The structure of male and female $A$. artemisiifolia flowers was observed in cultivated plants under controlled conditions in the 2000 vegetative season. The number of pollen grains produced by the stamen, flower, inflorescence and plant was determined. It was shown that in A. artemisiifolia flowers nonfunctional pistils occurred with a reduced ovary, performing the role of a pollen presenter. The pistils found in female flowers differed significantly in their morphological features from the pistils in male flowers. It was calculated that one stamrn produced an average of 3375 pollen grains, whereas one flower 16875 . A plant which produces 20 racemes may release over 420 million pollen grains into the atmosphere.

The Ambrosia pollen seasons in particular years had different patterns. In some years, the days of maximum concentration were in the second half of August, in other years in the first half of September. Over the 8-year period, the maximum daily concentration had a mean value of 116 pollen grains in $\mathrm{m}^{3}$ (31-311). Annual total concentrations of Ambrosia pollen grains ranged between 194 and 1200 grains, and it was 523 grains on the average. The pollen seasons were characterised by the occurrence of several-day-long interruptions in the presence of airborne pollen in the atmosphere of Lublin, which may indicate the long-distance transport of Ambrosia pollen.

Key words: Ambrosia artemisiifolia, floral morphology, pollen presenter, amount of pollen grains, pollen seasons, annual total concentrations

\section{INTRODUCTION}

Ambrosia artemisiifolia L. (Asteraceae) comes from North America. It was transferred to Europe, including Poland, together with a shipment of cereals at the end of $19^{\text {th }}$ century (H o l z fu s s , 1937). In Poland the occurrence of several species of the genus $\mathrm{Am}$ - brosia is recorded in different regions of the country: Ambrosia artemisiifolia L., A. psilostachya DC. and A. trifida L. (Tacik, 1971; Rutk ow ski, 1998; $\mathrm{Z}$ aj ąc and $\mathrm{Zaj}$ ąc, 2001). A. artemisiifolia has been noted, inter alia, in the Lublin region (F i j ałk o w s k i 1994), in Wrocław (M a l k i e w i c z and W ą s o w i c z, 2003), in the Upper Silesia region (Chłopek and Tokarska-Guzik, 2006). Ambrosia psilostachya sites have been described, among others, in Szczecin (Ćwikliński, 1968; P uc, 2004) and the Lublin region (Święs and Wrzesień, 2002).

Plants of the genus Ambrosia brought to Poland are most frequently encountered near railway tracks or at ruderal sites. They also grow on dry swards and at roadsides, and they sometimes occur as weeds in crops. In some locations, they are treated as species occurring temporarily (Fijałk owski, 1994; Św i ęs and Wrzesień, 2002). They belong to quarantined plants.

Ambrosia pollen grains are the most frequent cause of pollen allergy in North America (B o u s qu e $t$ et al. 2001). C o m to is (1998) defines representatives of the genus Ambrosia as allergophytes.

In $A$. artemisiifolia pollen grains, one of allergens with the strongest effect on humans (Amb a 1) is found, which causes allergies in many countries in an ever increasing number of people (C o $\mathrm{m}$ t o is , 1998; Jäg e r, 2000).

In Warsaw the frequency of positive skin tests to the ragweed pollen allergen is found to have increased in patients from $0.3 \%$ in 1998 to $1.5 \%$ in 2003 (Rapiejk o, 2004).

Ambrosia pollen has been found in the air of different Poland's cities for many years (K a s pr zy k, 1996, 2008; Stach and Silny, 1999; S tępalska et al. 2002; Malkiewicz and Wąsowicz, 2003; Weryszko-Chmielewska et. al. 2003; Puc, 
2004, 2006; Piotrowska and WeryszkoChmielewska, 2006).

The aim of the study was to investigate the biology of flowering of A. artemisiifolia growing in experimental plots in Lublin in order to determine the number of pollen grains produced by the stamen and the flower as well as to compare the pattern of Ambrosia pollen seasons in the years 2001-2008.

\section{MATERIALS AND METHODS}

Ambrosia artemisiifolia $\mathrm{L}$. seeds were obtained from the Botanical Garden in Dijon (France). Plants grew in experimental plots in Lublin under controlled conditions during the 2000 growing season. Over a dozen plants were subjected to observations.

Details of the structure of male and female flowers of the investigated Ambrosia artemisiifolia plants and their development were observed.

The number of male flowers in flower heads, the number of flower heads borne on one stem and on the plant as well as the diameter of flower heads were determined in ten plants. The number of pollen grains produced in the stamen was evaluated as a mean from 10 anthers from which separate smear slides stained with basic fuchsine were made. The number of pollen grains produced by a single flower, flower head and plant was determined.

The investigations of pollen concentrations were carried out by the volumetric method using a VPPS 2000 Lanzoni pollen trap. The sampler was placed in Lublin's city centre (Śródmieście) at a height of $18 \mathrm{~m}$. Daily Ambrosia pollen concentrations and annual total concentrations over the 8-year study period, 2001-2008, were calculated from the obtained aerial plankton samples.

\section{RESULTS}

\section{Floral morphology}

Ambrosia artemisiifolia is a herbaceous plant. In the conditions of Lublin, in 2000 the plants reached a height of $100 \mathrm{~cm}$. They flowered from 20 August till the end of October, producing on their stems numerous anemophilous flowers occurring in tiny flower heads (Figs $1 \mathrm{~A}, \mathrm{~B}$ ).

Flowers of this species are unisexual. The downward pointed flower heads (anthodia), with an average of 25 staminate flowers clustered in them (Tab. 1, Figs $1 \mathrm{C}, \mathrm{E}, \mathrm{F})$, are $4.0-6.5 \mathrm{~mm}$ in diameter. They are grouped in loose, terminal racemes composed of 50 flower heads, on the average (Tab. 1). The anthodium is protected by a cup-shaped involucre, made up of several fused bracts, which has a toothed edge or is provided with upward bent flaps (Fig. 1 D).
The first male flowers develop in the circumference of the anthodium. The flower height reaches $1.7 \mathrm{~mm}$, on the average, and its diameter $0.6 \mathrm{~mm}$. The yellow-green semi-transparent corolla is composed of 5 fused petals which form in their upper part free lobes opening only slightly at anthesis (Figs 2 A, B). Anthers are the first to come out through an opening formed at the apex of the corolla in some male flowers. In other male flowers, the apical portion of the non-functional pistil, which forms a brush-shaped pollen presenter, was observed to appear first between the corolla lobes (Figs $2 \mathrm{E}, \mathrm{F}, \mathrm{G}$ ). The pistil with a reduced ovary has a cylinder-shaped style (Figs 2 H, 3 E). In its upper portion, the style is provided with brush-shaped outgrowths which sweep out and raise pollen, released in the flower inwardly from the bursting anthers already inside the closed corolla. This pistil in the bud reaches the half-height of the corolla (Fig. 2 C) and gradually elongates as the flower develops (Fig. 2 D).

The stamens (5) observed in the buds of male flowers were fused by their heads, but at anthesis they separated (Figs 3 A, B). The filaments were very short in the bud (Fig. 3 F). There was an outgrowth at the apex of the elongated anther (Figs $3 \mathrm{~B}, \mathrm{~F}$ ). At anthesis, the anthers stuck out much above the corolla (Fig. 3 A).

Female flowers are gathered in single-flowered anthodia subtended by small bracts. These anthodia grow in clusters beneath the male inflorescences (Figs 4 A, C). They are subtended by several hairy bracts. The female flower is composed of one pistil with an inferior ovary and two filiform red-coloured stigmas (Fig. 4 B) which elongate significantly during flowering (Fig. $4 \mathrm{C}$ ). In the upper portion of the receptacle fused with the ovary, the calyx is visible, forming a ring of tiny nodules which remain later on the fruit. In the basal part, the pistil's stigmas are enclosed by strongly reduced, hairy petals of the corolla (Fig. 4 B). The share of female flower heads in the total number of inflorescences in the investigated plants was small.

It was found that one stamen produced 3375 pollen grains, on the average (Tab. 1). The calculations show that one flower produces an average of 16875 grains, one flower head 421875 grains, whereas a raceme 21093750 pollen grains. A plant which produces 20 racemes releases on the average over 420 million pollen grains into the atmosphere. These grains are tricolporate. They reach an average size of $18 \times 20$ $\mu \mathrm{m}$. The exine surface is covered with spinules with a length of about $1 \mu \mathrm{m}$ (Figs $3 \mathrm{G}, \mathrm{H})$.

\section{Pollen seasons}

The start of the Ambrosia pollen season was noted in Lublin in the study years (2001-2008) between 5 August (2003) and 28 August (2002). The pollen 
Table 1

Characteristics of flowers and inflorescences of Ambrosia artemisiifolia L. $(\mathrm{n}=10)$.

\begin{tabular}{|c|c|c|}
\hline $\begin{array}{l}\text { Investigated } \\
\text { parametres }\end{array}$ & $\begin{array}{l}\text { Average } \\
\text { values }\end{array}$ & Min. - Max. \\
\hline Number of anthodiums in raceme & 50 & $10-90$ \\
\hline $\begin{array}{l}\text { Number of male flowers } \\
\text { in anthodium }\end{array}$ & 25 & $12-60$ \\
\hline $\begin{array}{l}\text { Number of female flowers } \\
\text { in inflorescence }\end{array}$ & 3 & $2-7$ \\
\hline Number of pollen grains in stamen & 3.375 & $3.010-3.850$ \\
\hline $\begin{array}{l}\text { Number of pollen grains } \\
\text { producted per flower }\end{array}$ & 16.875 & $15.050-19250$ \\
\hline $\begin{array}{l}\text { Number of pollen grains } \\
\text { per anthodium }\end{array}$ & 421.875 & $180.600-1.155 .000$ \\
\hline $\begin{array}{l}\text { Number of pollen grains } \\
\text { producted per raceme }\end{array}$ & 21.093 .750 & $1.806 .000-103.950 .000$ \\
\hline $\begin{array}{l}\text { Number of pollen grains } \\
\text { producted per plant ( } 20 \text { racemes) }\end{array}$ & 421.875 .000 & $36.120 .000-2.079 .000 .000$ \\
\hline
\end{tabular}

Table 2

Concentrations of Ambrosia pollen grains in Lublin in August, September and October in 2001-2008.

\begin{tabular}{cccccccccc}
\hline month & 2001 & 2002 & 2003 & 2004 & 2005 & 2006 & 2007 & 2008 & average \\
\hline VIII & 373 & 193 & 73 & 317 & 399 & 73 & 119 & 83 & 203.7 \\
IX & 53 & 987 & 199 & 96 & 221 & 142 & 57 & 625 & 297.5 \\
& & & & & & & & & \\
X & 8 & 20 & 12 & 22 & 20 & 65 & 16 & 0 & 20.4 \\
\hline
\end{tabular}

seasons of this taxon had different patterns (Figs 5, 6). In some years, the days of maximum Ambrosia pollen concentrations were in the second half of August $(2001,2004,2005,2007)$, in other years, in the first half of September $(2002,2003,2008)$. But in 2006 two days with the same, and at the same time, the highest pollen concentration were distinguished (Figs 5, 8).
The pollen season pattern covering mean concentrations from the eight-year study is characterised by the presence of two peaks. The first peak is seen on 20 August, the other one on 4 September (Fig. 7). It results from the occurrence of maximum concentrations at different dates in the study years. In particular years, the maximum pollen concentrations ranged between 

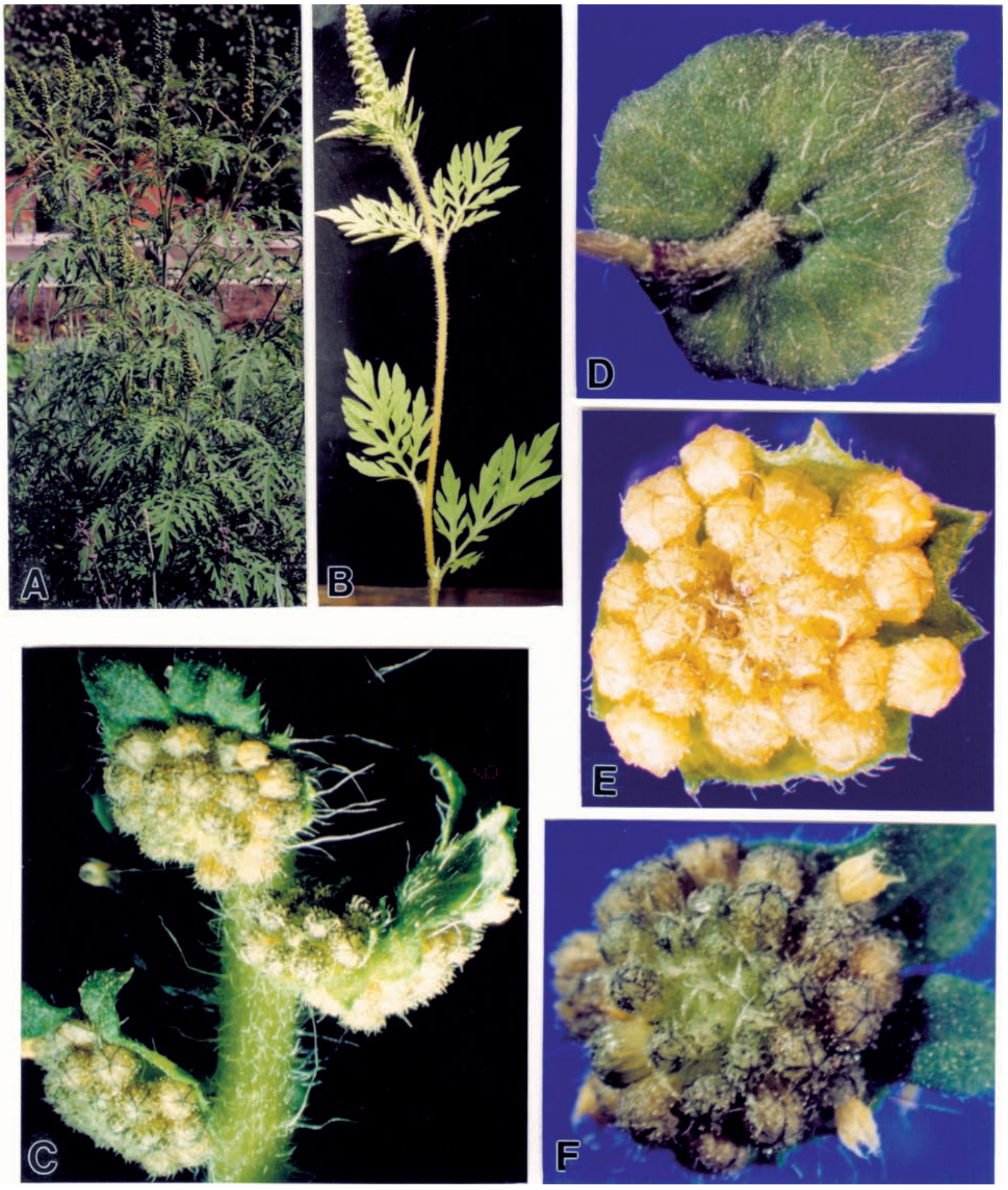

Fig. 1. Ambrosia artemisiifolia

A - Flowering plant,

B - Plant before the start of flowering with a terminal raceme formed from numerous male flower heads,

$\mathrm{C}$ - Portion of the raceme with male flower heads (x 7),

$\mathrm{D}$ - Upper side of the anthodium with the visible involucral bract (x 14),

E - Male flower head before the start of flowering (x 14),

$\mathrm{F}$ - Anthodium with blooming male flowers (x 14). 

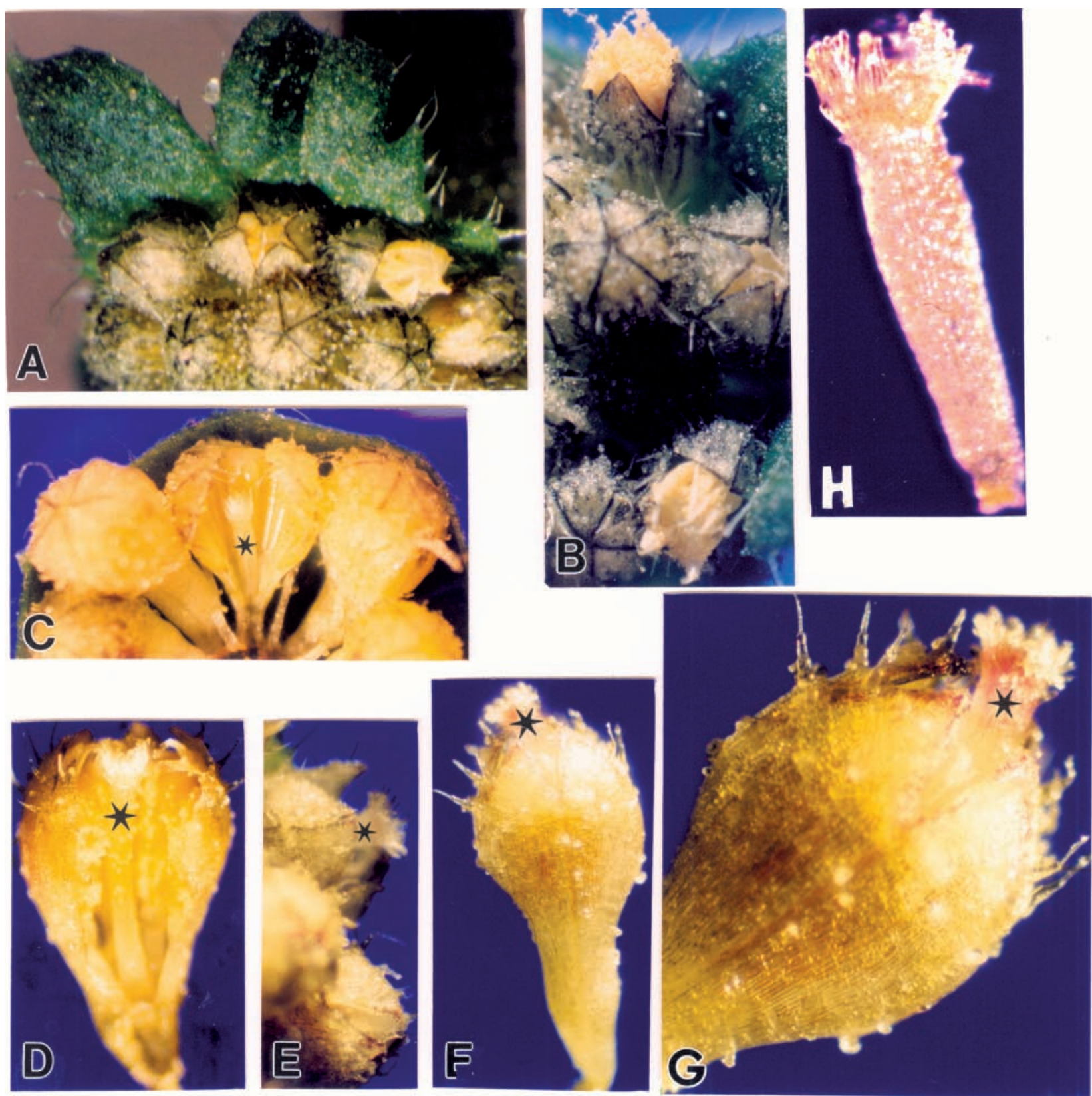

Fig. 2. Portions of Ambrosia artemisiifolia male inflorescences.

A, B - Portions of anthodia with blooming flowers in which pollen-shedding stamens grow above the corolla $(\mathrm{A}-\mathrm{x} 30, \mathrm{~B}-\mathrm{x} 40)$,

C, D - Male flowers with the non-functional pistil performing the role of the pollen presenter (asterisk) (C $-\mathrm{x} 40$, $\mathrm{D}-\mathrm{x} 60$ ),

$\mathrm{E}, \mathrm{F}, \mathrm{G}-$ Male flowers, in which the pollen presenter (asterisk) is the first to appear during flowering (E, $\mathrm{F}-\mathrm{x} 30$, $\mathrm{G}-\mathrm{x} 100$ ),

$\mathrm{H}$ - The pistil's style with a brush-shaped pollen presenter (x 150). 

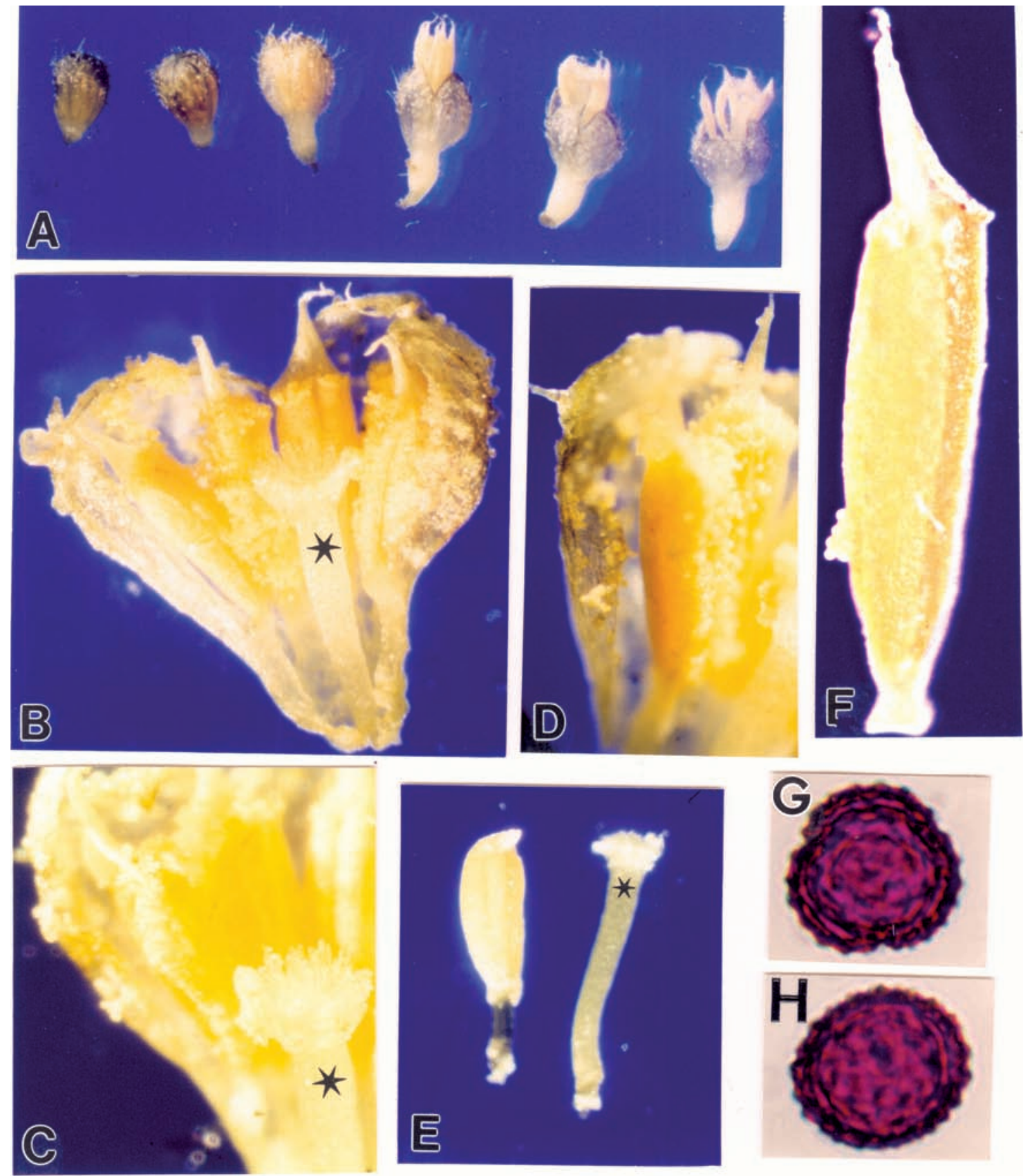

Fig. 3. Male flowers, their portions and Ambrosia artemisiifolia pollen grains.

A - Different growth stages of male flowers coming from one anthodium (x 20),

$\mathrm{B}, \mathrm{C}-$ Portions of male flowers with the involucre, stamens and the pollen presenter (asterisk) $(\mathrm{B}-\mathrm{x} 80, \mathrm{C}-\mathrm{x} 100)$, D - Burst anthers releasing pollen (x 100),

E - Stamen and the style of the non-functional pistil from a male flower (asterisk), (x 50),

F - Stamen excised from a flower bud (x 200),

$\mathrm{G}-$ Pollen grain in polar view (x 1300),

$\mathrm{H}$ - Pollen grain in equatorial view (x 1300). 

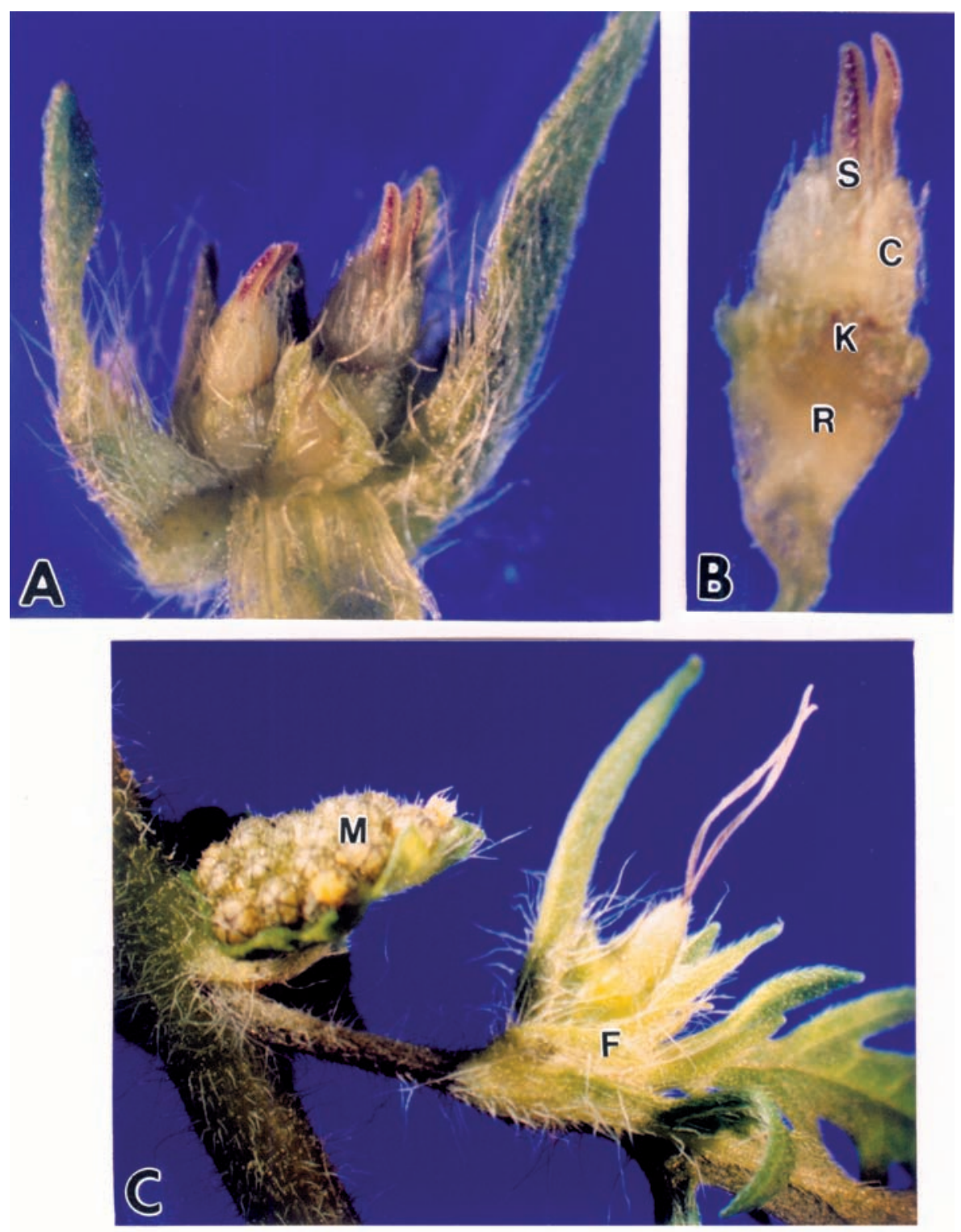

Fig. 4. Ambrosia artemisiifolia female flowers.

A - Cluster of several female flowers at the start of flowering, subtended by hairy bracts (x 14),

B - Not fully developed female flower: R - receptacle with the ovary, K - calyx, C - corolla, S - stigmas. (x 25), $\mathrm{C}$ - Anthodium with male flowers (M) and female flower (F) at full flowering (elongated stigmas) (x 7).

31 and 311 pollen grains in $\mathrm{m}^{3}$ per day. The lowest concentration was in 2006, and the highest one in 2002. Very high concentrations also occurred in the years 2001 and 2008 (Fig. 8). The 8-year mean maximum concentration was 116 pollen grains in $\mathrm{m}^{3}$ per day.

A comparison of pollen sums in particular months: August, September and October, is presented in Tab. 2. The comparison shows that in some years higher pollen sums were recorded in August, whereas in others in September. The mean number of pollen grains from the study years was the highest in September. The seasonal pollen index (SPI), that is, the annual total concentration of Ambrosia pollen grains, ranged between 194 and 1200 grains (Fig. 9). The largest amount of pollen grains was recorded in 2002, whereas the lowest in 2007. Relatively high annual sums were also obtained in the years 2008 (712 pollen grains) and 2005 (646 pollen grains). The 8-year mean SPI reached 523 pollen grains. 

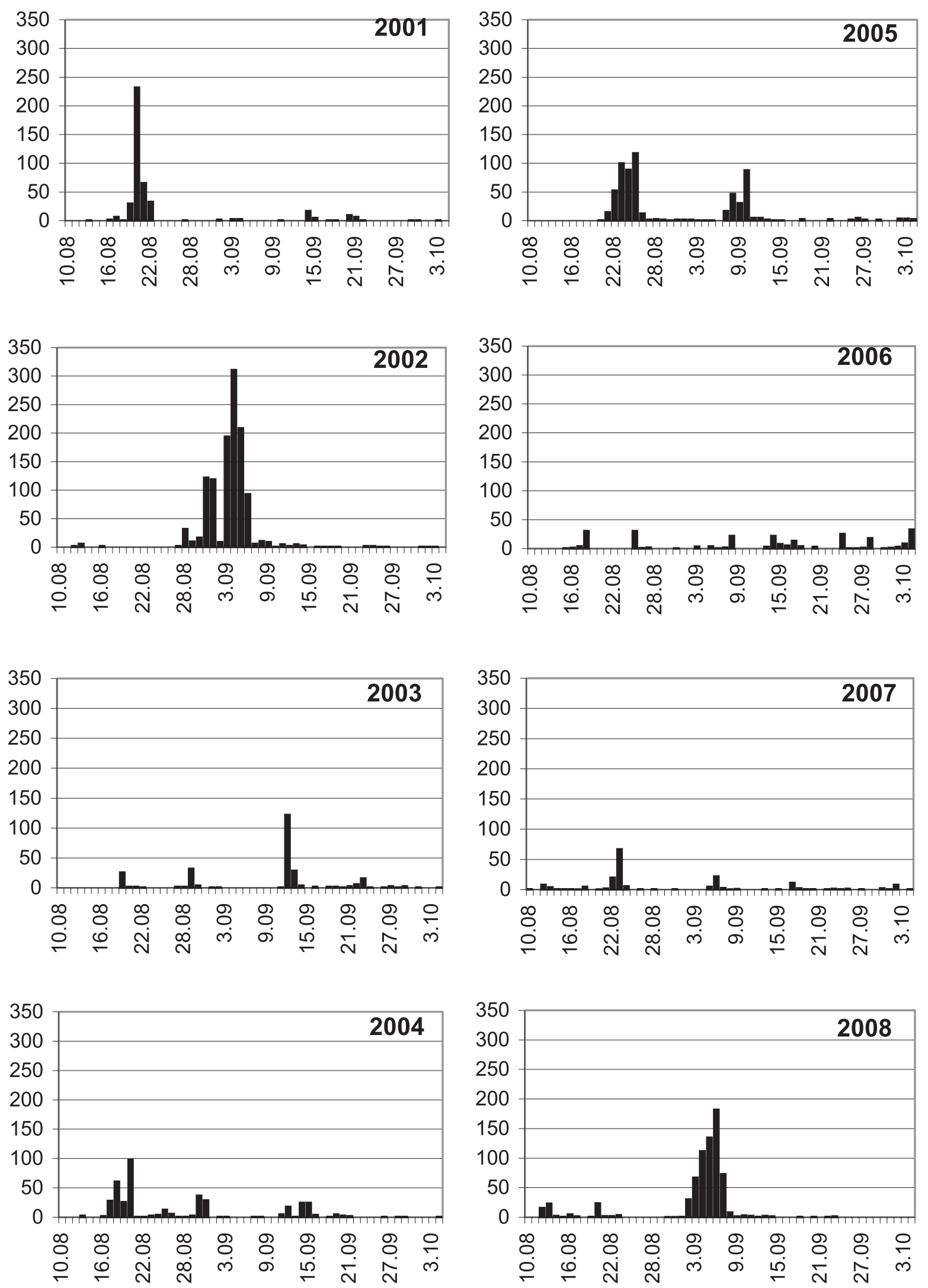

Fig. 5. Dynamics of Ambrosia pollen seasons in Lublin, 2001-2008. 


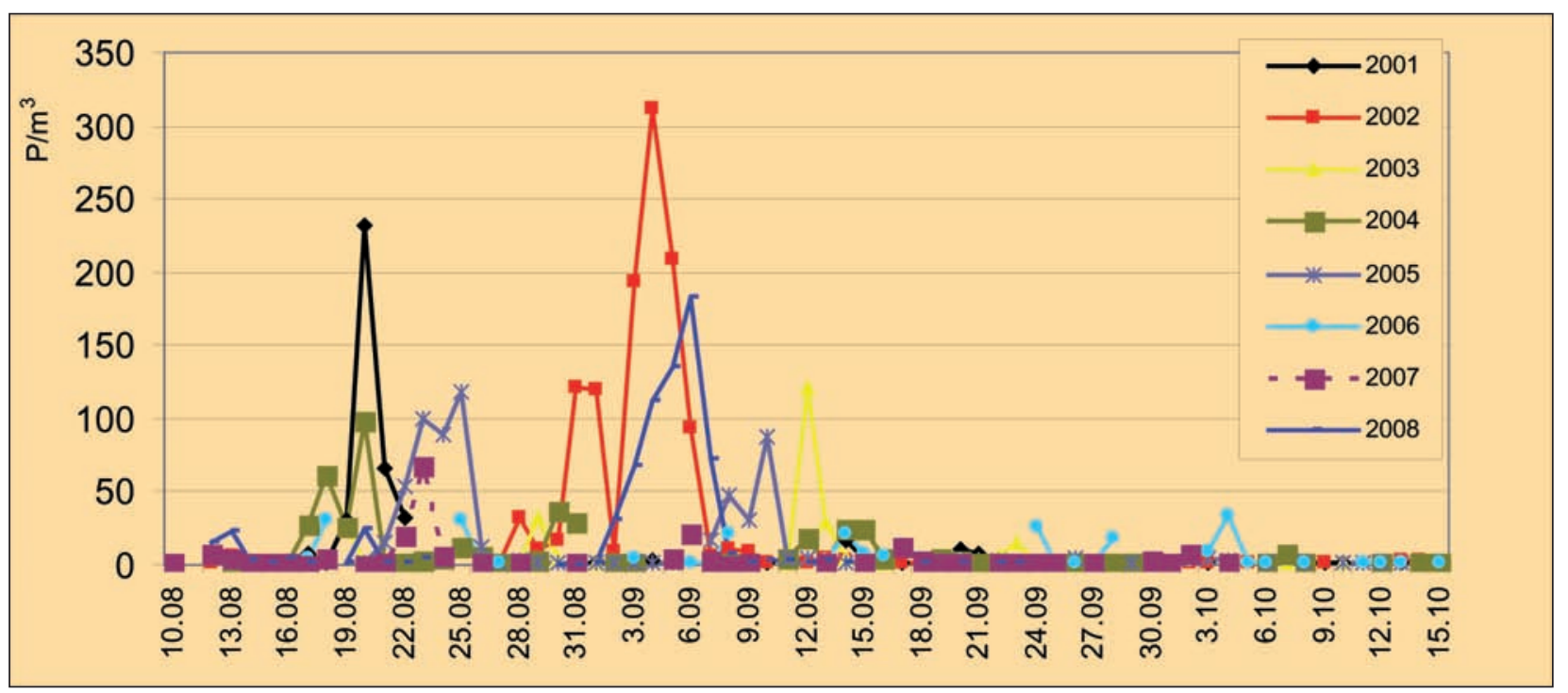

Fig. 6. Comparison of Ambrosia pollen season in Lublin, 2001-2008.

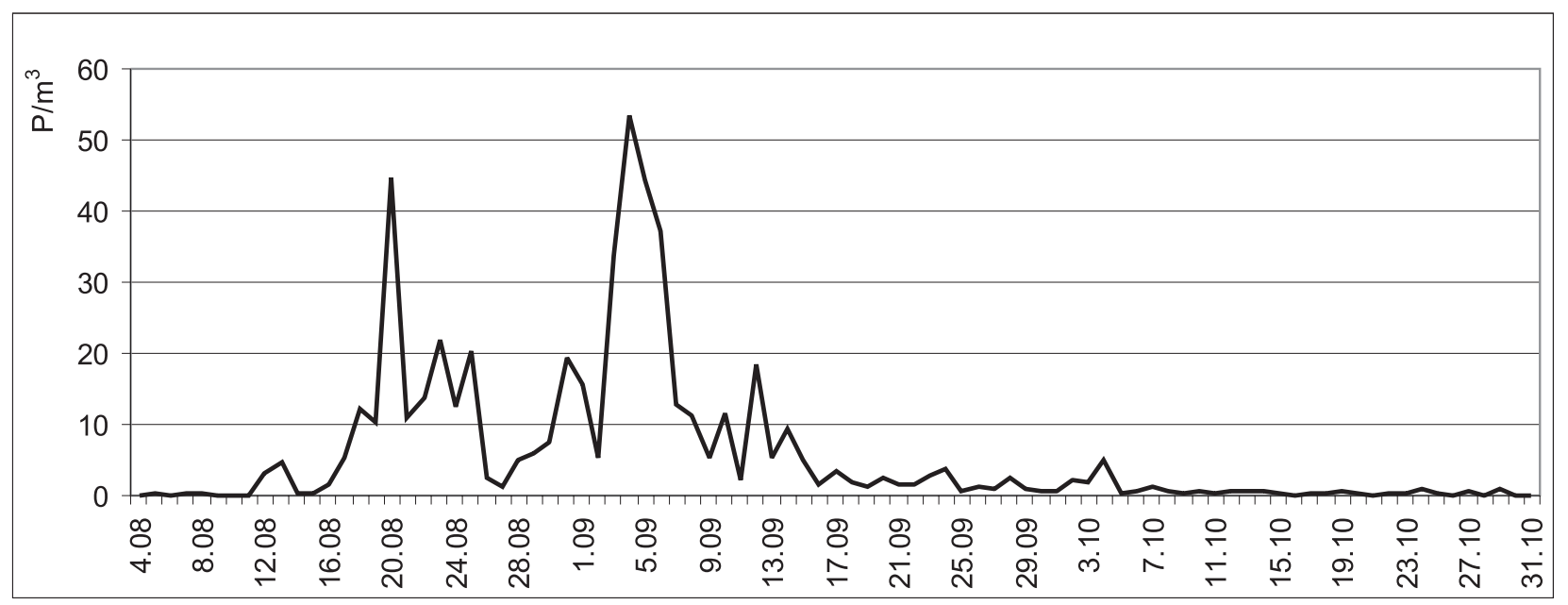

Fig. 7. Average concentrations of Ambrosia pollen grains in the air of Lublin on the basis of eight-year-long investigations (20012008). 


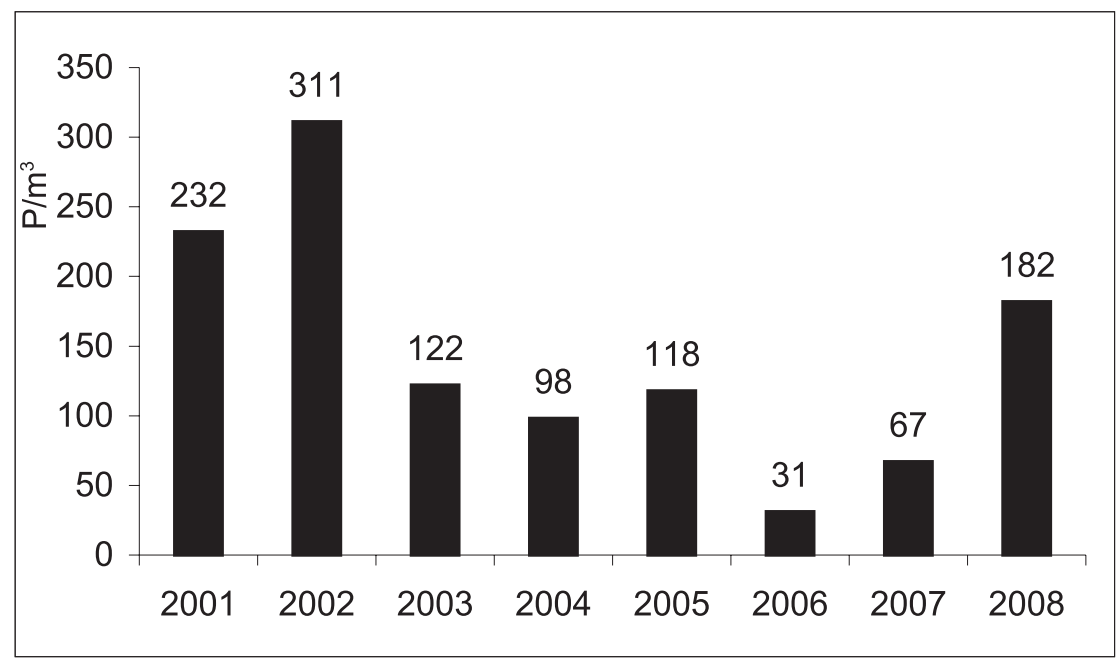

$\begin{array}{ll}2001-20.08 & 2005-25.08 \\ 2002-4.09 & 2006-18.08 \text { and } 25.08 \\ 2003-12.09 & 2007-23.08 \\ 2004-20.08 & 2008-6.09\end{array}$

Fig. 8. Maximum Ambrosia pollen concentrations in the years 2001-2008 and dates of their occurrence.

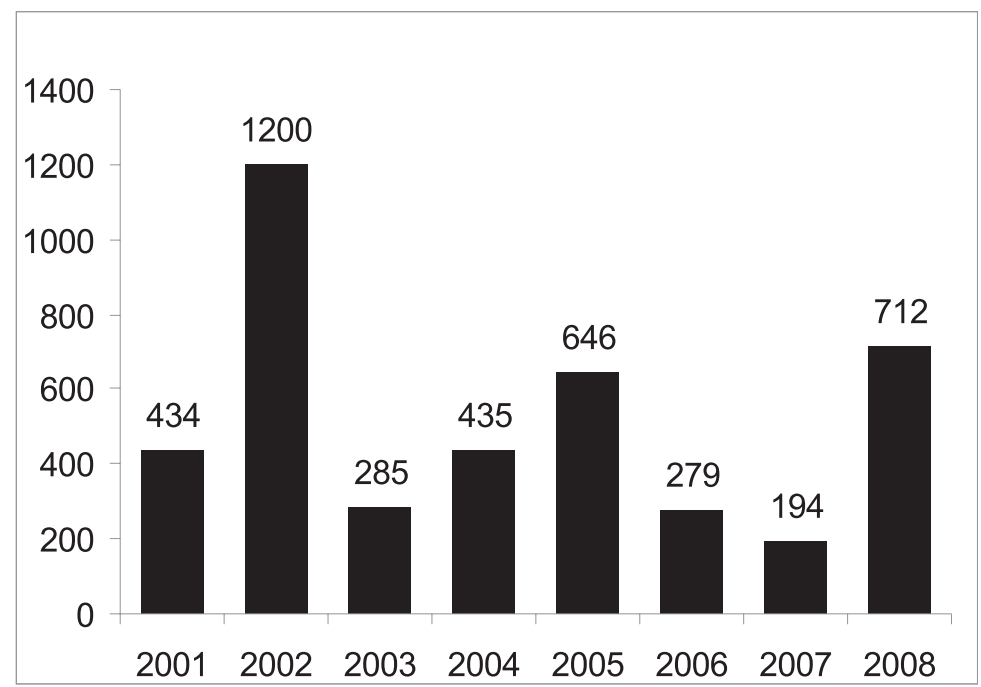

Fig. 9. Annual total concentrations of Ambrosia pollen grains in Lublin, 2001-2008. 


\section{DISCUSSION}

\section{Ambrosia flower morphology}

On one stem of the investigated $A$. artemisiifolia plants, we found the occurrence of 10-90 (50 on the average) male flower heads. But B a s s et and Crompton (1975) report that 10-200 of such flower heads may occur at the top of stems of this species. The diameter of the investigated male flower heads was 4.0-6.5 mm. Tacik (1971) mentions similar dimensions (a diameter of 5-7 mm) of male flower heads of this taxon.

Our calculations show that $12-60$, on the average 25 , male flowers formed in one anthodium. Ta c i k (1971) reports that from several up to 20 flowers are found in the anthodium of Ambrosia genus representatives.

Male flowers have a yellow and green coloured fused corolla with five free lobes at the apex. In our study, we found that there were 5 stamens in the male flower and 1 non-functional pistil with a reduced ovary as well as a well-developed style and a stigma. The brush-shaped outgrowths on the stigma, forming the pollen presenter, support the functioning of the male elements in the flower, raising pollen grains released from the anthers above the level of the corolla lobes. It seems that such a structure of the flower is a remnant of this plant's adaptation to entomophily, and the reduction of the ovary, with the pollen presenter left/formed at the apex of the style, is one of ecological features facilitating external pollen exposition under the conditions of wind pollination. Attention is attracted to a completely different structure of the pistil in functionally male and female flowers. In female flowers, a well-developed ovary and the presence of two long stigmas of the pistil, typical for anemophilous plants, are noticeable.

In Ambrosia, female flowers occur in single-flowered heads (Tacik, 1971; Basset and Crompton, 1975) which form small clusters in the axils of the upper bracts, beneath the male flower heads. Tacik (1971) reports that clusters of female flowers are most frequently made up of 5-6 flowers, whereas in the investigated individuals we observed 27 flowers subtended by several involucral bracts. In the conditions of Lublin, clusters of female flowers were most frequently composed of 3 flower heads.

The reduced calyx occurring in female flowers forms a ring of nodulelike outgrowths which remain on the fruit, developing into a circle of tiny prickles. Tacik (1971) finds that the number of differentshaped prickles formed on the achene in A. artemisiifolia is within the range of 4-7. According to data reported by Basset and Crompton (1975), achenes in this species are $3.5 \mathrm{~mm}$ in length and $2.5 \mathrm{~mm}$ in width. They form a terminally located beak with a length of $2 \mathrm{~mm}$ surrounded by a circle of thorns reaching a length of up to 1 $\mathrm{mm}$. The fruit coat is lignified. It seems that the beak located at the apex of the achene is formed from reduced corolla elements, and the thorns from the corolla outgrowths.

In our study, we found that the number of pollen grains produced by the stamen was 3375 , on the average. But the number of pollen grains released by a plant producing 20 inflorescence stems may reach 421875 000. Com to is (1998) also reports that one Ambrosia plant can produce tens up to hundreds of millions of pollen grains.

\section{A comparison of Ambrosia pollen seasons}

Lublin belongs to these Poland's cities in which high and very high Ambrosia pollen concentrations have been noted over the period of the last eight years.

A comparison of annual sums and daily maximum concentrations of Ambrosia pollen grains in 6 Poland's cities in the years 2001-2005 demonstrates that both the highest annual sums and the highest daily pollen concentrations occurred in Lublin. The mean annual sums from the abovementioned 5-year period were as follows for the particular cities: Lublin 602, Rzeszów 332, Sosnowiec 331, Szczecin 196, Kraków 179 and Poznań 121. In 2002 the highest annual pollen sums were recorded in most of the abovementioned cities, however, the value obtained for Lublin (1200 grains) was several times higher than in Kraków (200 grains) (Chłopek and Dąbrowska, 2006; Kasprzyk, 2006; Myszkowska, 2006; Puc, 2006; Stach, 2006). In the abovementioned 5-year period, the highest daily Ambrosia pollen concentrations were also recorded in 2002.

In four of the abovementioned six cities, located at a distance of several hundred kilometres from one another, the peak day was recorded on 4 September 2002 (Chłopek and Dąbrowska, 2006; Kasprzyk, 2006; P u c, 2006).

The years 2006 and 2007 were characterised by low annual sums of Ambrosia pollen grains both in Lublin and in several other cities in Poland ( $\mathrm{R} \mathrm{a}$ piejko et al. 2006; Lipiec et al. 2008). In 2006 the highest annual totals occurred in Sosnowiec (534 grains), Wrocław (207 grains) and Lublin (193 grains), whereas in 2007 in Sosnowiec (234 grains), Lublin (172 grains) and Warsaw (159 grains). The calculation of the mean annual sum of Ambrosia pollen for the years 2001-2007 for several Poland's cities shows that the highest number of pollen grains was recorded in Lublin (482), and then in Sosnowiec (346).

It can be concluded from the analysis of the pattern of the Ambrosia pollen seasons that large quantities of airborne pollen of this taxon found in the air of Lublin may come from the long-distance transport. It is indicated by the pollen seasons, distributed over all the years of study, with the alternate occurrence of 
days with Ambrosia pollen content in the air and days when there were no such airborne pollen. In the pattern of the pollen seasons from the years 2001-2008, one can observe several-day-long interruptions in the inflow of Ambrosia pollen, which is probably associated with meteorological conditions. The effect of meteorological conditions on the presence of airborne Ambrosia pollen in the air of Lublin has been demonstrated in our previous paper (Piotrowska and WeryszkoChmielewska, 2006).

Our observations and consultations with other botanists show that no Ambrosia plant individuals have been found in Lublin. The nearest locations of this plant have been found over $60 \mathrm{~km}$ away from $\mathrm{Lu}-$ blin (Ś wi ęs and Wrzesień 2002), which confirms the long-distance transport of this pollen.

In our previous paper we have shown that maximum intradiurnal Ambrosia pollen concentrations occur at different times of the day: before noon, in the afternoon and at night. On most days with high Ambrosia pollen concentrations, the largest amount of pollen grains was recorded between 4 and $8 \mathrm{pm}$ (P i o trow ska and Weryszko-Chmielewska, 2006).

The long-distance transport of Ambrosia pollen also applies to other Poland's regions. K a s p r zy k (2008) has shown that a large portion of Ambrosia pollen recorded in Rzeszów comes from the long-distance transport. The influence of movements of air masses from the south over Poland on the occurrence of Ambrosia pollen in Kraków, Sosnowiec, Łódz, Poznań, Szczecin, Gdańsk, Rzeszów and Lublin has also been found (S mith et al. 2008).

\section{Acknowledgments}

We would like to thank Mr. Janusz Matusiewicz, MSc, for taking photos of Ambrosia artemisiifolia flowers.

\section{REFERENCES}

B a s s e t I. J., Crompton C. W., 1975. The biology of Canadian weeds. Ambrosia artemisiifolia L. and A. psilostachya DC. Can. J. Plant Sci. 55: 463-476.

Bousquet J., Van Cauwenberge P., Khaltaev N., 2001. Allergic rhinitis and its impact on asthma. J. Allergy Clin. Immunol. 108 (5 Suppl): 147-334.

Chłopek K., Dąbrowska K., 2006. Pyłek wybranych taksonów roślin w powietrzu Sosnowca, 2001-2005. / Pollen of selected plant taxa in the air of Sosnowiec, 2001-2005. [In:] E. Weryszko-Chmielewska (Ed) Pyłek roślin w aeroplanktonie różnych regionów Polski. Katedra i Zakład Farmakognozji Akademii Medycznej, Lublin, 2006: 59-69.

Chłopek K., Tokarska-Guzik B., 2006. Pyłek ambrozji (Ambrosia) w aeroplanktonie Górnego Śląska. /
Ragweed (Ambrosia) pollen in aeroplankton of Górny Śląsk. Acta Agrobot. 59 (1): 335-345.

Comto is P., 1998, Ragweed (Ambrosia sp.): the Phoenix of allergophytes. $6^{\text {th }}$ Int. Cong. on Aerobiology, Satellite Symposium Proceedings: Ragweed in Europe. ALK Abelló.

Ćwikliński E., 1968. Neofity terenów kolejowych województwa szczecińskiego. / Neophytes of railway areas in the Szczecin region. Materiały Zakładu Fitosocjologii Stosowanej U.W. 25: 125-138.

Fijałkowski D., 1994. Flora roślin naczyniowych Lubelszczyzny. / Flora of vascular plants of the Lublin region. Lubelskie Towarzystwo Naukowe, Lublin.

Holzfus s J., 1937. Beitrag zur Adventivflora von Pommern. Abhandl. u. Berichte d. Pommersch. Naturforsch. Gesellsch. 16: 94-130.

Jäger S., 2000. Ragweed (Ambrosia) sensitisation rates correlate with the amount of inhaled airborne pollen. A 14-year study in Vienna, Austria, Aerobiologia, 16: 149-153.

K a sprzyk I., 1996. Palynological analysis of airborne pollen fall in Ostrowiec Świętokrzyski in 1995. Ann. Environ. Med. 3 (2): 83-66.

K a s przyk I., 2006. Pyłek wybranych taksonów roślin w powietrzu Rzeszowa, 2001-2005. / Pollen of selected plant taxa in the air of Rzeszów, 2001-2005. [In:] E. Weryszko-Chmielewska (Ed). Pyłek roślin w aeroplanktonie różnych regionów Polski. Katedra i Zakład Farmakognozji Akademii Medycznej, Lublin, 2006: 93-103.

Kasprzyk I., 2008. Non-native Ambrosia pollen in the atmosphere of Rzeszów (SE Poland); evaluation of the effect of weather conditions on daily concentrations and starting dates of the pollen season. Int. J. Biometeorol. 52: $341-351$.

Lipiec A., Weryszko-Chmielewska E., Piotrowska K., Malkiewicz M., Chłopek K., Puc M., Siergiejko Z., Zielnik-Jurkiewicz B., Rapiejko A., Modrzyński M., Rataj czak J., 2008. Analiza stężenia pyłku ambrozji w wybranych miastach Polski w roku 2007. / The analysis of ragweed pollen count in selected Polish cities in 2007. Alergoprofil, 4 (1): 49-54.

Malkiewicz M., Wąsowicz A., 2003. Ambrosia pollen grains in aeroplankton of Wrocław, Ann. UMCS, sect. EEE, 13: 333-339.

Myszkowska D., 2006. Pyłek wybranych taksonów roślin w powietrzu Krakowa, 2001-2005. / Pollen of selected plant taxa in the air of Kraków, 2001-2005. [In:] E. Weryszko-Chmielewska (Ed) Pyłek roślin w aeroplanktonie różnych regionów Polski. Katedra i Zakład Farmakognozji Akademii Medycznej, Lublin, 2006: 21-30.

Piotrowska K., Weryszko-Chmielewska E., 2006. Ambrosia pollen in the air of Lublin, Poland. Aerobiologia, 22: 151-158.

Puc M., 2004. Ragweed pollen in the air of Szczecin, Ann Agric. Environ Med. 11: 53-57.

P u c M., 2006. Ragweed and mugwort pollen in Szczecin, Poland. Aerobiologia, 22: 67-78. 
Rapi ejk o P., 2004. Ambrozja i inne dotychczas nie występujące alergeny wziewne. / Ragweed and other airborne allergens not occurring before. Alerg. Astma Immunol. 9 (Supl.): 52-54.

Rapiejko P., Malkiewicz M., Lipiec A., WeryszkoChmielewska E., Piotrowska K., Cecherz K., Myszkowska D., Chłopek K., Puc M., Rapiejko A., Stankiewicz W., Stasiak-Barmuda A., Tarase wi c z A., 2006. Analiza stężenia pyłku ambrozji w wybranych miastach Polski w 2006 r. / The analysis of ragweed pollen count in selected Polish cities in 2006. Alergoprofil, 2 (4): 51-58.

Rutkowski L., 1998. Klucz do oznaczania roślin naczyniowych Polski niżowej. Wyd. Naukowe PWN, Warszawa.

Smith M., Skjøth C. A., Myszkowska D., Uruska A., Puc M., S ta ch A., B a lwi erz Z., Chłopek K., Piotrowska K., Kasprzyk I., Brandt J., 2008. Long-range transport of Ambrosia pollen to Poland. Agricult. For. Meteor., 148: 1402-1411.

S tach A., 2006. Pyłek wybranych taksonów roślin w powietrzu Poznania, 2001-2005. / Pollen of selected plant taxa in the air of Poznan, 2001-2005. [In:] E. WeryszkoChmielewska (Ed) Pyłek roślin w aeroplanktonie różnych regionów Polski. Katedra i Zakład Farmakognozji Akademii Medycznej, Lublin, 2006: 31-47.

S t a c h A., S i l n y W., 1999. Pyłek dalekiego transportu w aeroplanktonie Poznania w latach 1995-1997 (Wybrane taksony alergogenne). / Long-transport pollen in aeroplankton of Poznań in the years 1995-1997 (Selected allergenic taxa). Biblioth. Fragm. Agron. 6: 209-016.

Stępalska D., Szczepanek K., Myszkowska D., 2002. Variation in Ambrosia pollen concentration in Southern and Central Poland in 1982-1999, Aerobiologia, 18: 13-22.

Święs F., Wrzesień M., 2002. Rare vascular plants of the railway areas in Central-Eastern Poland. I. Lublin Upland, eastern part, Roztocze, Volhynia Upland, Ann. UMCS, sect. C, 57: 95-117.

Tacik T., 1971. Ambrozja (Ambrosia L.), [In] B. Pawłowski and A. Jasiewicz (Eds), Flora Polska. PWN, Warszawa - Kraków, 222-225.

Weryszko-Chmielewska E., Pi otrowska K., Czernećkyj M., 2003. Ambrosia and Iva pollen in the air of Lublin and Lvov, Ann. UMCS, sect. EEE, 13: 341348.
Zając A., Zając M., 2001. (Eds), Distribution Atlas of Vascular Plants in Poland, Wyd. Instytutu Botaniki UJ, Kraków.

\section{Cechy ekologiczne kwiatów \\ Ambrosia artemisiifolia $\mathrm{L}$. oraz charakterystyka sezonów pyłkowych Ambrosia L. w warunkach Lublina (Poland) w latach 2001-2008}

\section{Streszczenie}

W pracy badano biologię kwitnienia Ambrosia artemisiifolia L. oraz scharakteryzowano przebieg sezonów pyłkowych Ambrosia w Lublinie w latach 2001-2008. Budowę kwiatów męskich i żeńskich A. artemisiifolia obserwowano u roślin uprawianych w warunkach kontrolowanych w sezonie wegetacyjnym 2000 roku. Określono liczbę ziaren pyłku wytwarzanych przez pręcik, kwiat kwiatostan i roślinę. Wykazano, że w kwiatach męskich $A$. artemisiifolia występują niefunkcjonalne słupki ze zredukowaną zalążnią, pełniące rolę prezenterów pyłkowych. Słupki znajdujące się w kwiatach żeńskich różniły się znacznie cechami morfologicznymi od słupków w kwiatach męskich. Obliczono, że jeden pręcik wytwarza średnio 3375 ziaren pyłku, jeden kwiat 16 875. Roślina, która wytwarza 20 gron może uwolnić do atmosfery ponad $420 \mathrm{mln}$ ziaren pyłku.

Sezony pyłkowe Ambrosia miały w poszczególnych latach różny przebieg. Dni maksymalnych koncentracji przypadały w niektórych latach w drugiej połowie sierpnia, w innych w pierwszej połowie września. Maksymalne dobowe stężenie miało w ciągu 8 lat średnią wartość 116 ziaren pyłku w m³ (31-311). Roczne sumy stężeń ziaren pyłku Ambrosia wahały się od 194 do 1200 ziaren, średnio wynosiły 523 ziarna. Sezony pyłkowe charakteryzowały się występowaniem kilkudniowych przerw w obecności pyłku w atmosferze Lublina, co może wskazywać na daleki transport pyłku Ambrosia. 